\title{
1. Experiential learning at Babson College
}

This book describes an approach to experiential learning that we have practiced at Babson College over several decades. Founded in 1919, Babson is preparing to begin its next hundred years, and our focus on experiential learning continues with a renewed and even stronger commitment to this type of learning playing a major role in the strategic vision for the college. According to the Center for Creative Leadership (Scisco et al., 2017), 'Learning from experience is the number one way that leaders develop.' We believe that learning from experience is a major way that students develop as well. In addition, work from the Gallup Organization (Levy \& Sidhu, 2013) stated that schools could have a significant effect on their students' long-term work success by incorporating twenty-first-century skills-specifically real-world problem-solving and collaboration skills - into curricula through project-based experiential learning. We wrote this book with the intention of sharing what we've learned with other educators and administrators who wish to establish, run and manage field-based learning using real-world consulting projects for their own students.

According to Professor Eric Cox (2019), the roots of experiential learning are often attributed to philosopher John Dewey. In 1916, Dewey stated that human knowledge and education have their foundation in inquiry, which in turn is rooted in human experience. Dewey used the phrase 'to learn from experience' to assert the following idea, as adapted by Cox (2019):

Humans are always learning through their interactions with the world around them, suggesting that the best form of education will be one that emphasizes creating meaningful experiences for learners in recognition of the natural way in which individuals learn. Doing so not only helps the acquisition of knowledge and skills in particular areas, but enables individuals to apply the concepts of learning from experience to other areas of their life, creating, in effect, lifelong learners who are able intentionally to shape their life experiences into continual educational moments.

At Babson, we are focused on creating a lifelong learning model for all students, alumni, executives, educators and others who have been part of our educational and entrepreneurial experiences. The chapters that follow offer suggestions for project advisors and for others in how to organize and success- 
fully manage a program of experiential learning in which student consulting teams work with clients for an entire semester.

\section{DIFFERENT APPROACHES FOR RUNNING STUDENT CONSULTING PROJECTS}

There are many approaches available that utilize student consulting teams in higher education. The most commonly practiced approach in most colleges uses faculty members as project advisors to manage one or more consulting projects in a semester. Sometimes faculty from different academic disciplines are assigned to manage consulting projects based on their expertise in the projects' corresponding industry or discipline.

The main approach used in our graduate programs at Babson is one in which a faculty member - chosen based on that faculty member's experience in advising or managing consulting teams - serves as project advisor to approximately six teams for a semester-long project. In this approach, multiple faculty advisors each semester teach students the necessary frameworks and strategies for successful client engagements.

In another approach (also used in one of our graduate programs at Babson), consulting projects comprise a major component of an existing strategy course in which the course's faculty member is also the project advisor to all members of the class, which typically divides into seven teams. In that class, the professor presents content relevant to consulting in addition to the strategy focus of the course.

\section{BABSON COLLEGE'S UNDERGRADUATE MANAGEMENT CONSULTING FIELD EXPERIENCE (MCFE) PROGRAM}

The undergraduate Management Consulting Field Experience-called MCFE (pronounced 'mick-fee') — program at Babson College has consistently been one of the school's signature learning experiences and has provided a unique opportunity for our students to provide consulting to clients and businesses. The program's curriculum demonstrates a commitment to learning through experiences that are relevant and grounded in a solid academic framework. While the MCFE program originally started in the 1970s, the current model used in our undergraduate program began in 1988 with two related goals: (1) to give undergraduate students a team-based experience working as consultants in analyzing and solving challenging real-world business problems, and (2) to provide Babson MBA students, with faculty supervision, an opportunity to be project advisors and to develop hands-on leadership and coaching skills with real clients and student teams. 
While we have drawn on experiences in both our undergraduate and graduate student consulting programs, the chief source of our knowledge comes from running the undergraduate MCFE program at Babson. In the Carnegie Foundation for the Advancement of Teaching's national study of undergraduate business education (and as published in the book Rethinking Undergraduate Business Education (Colby et al., 2011)), the undergraduate MCFE course at Babson was specifically cited for using a 'different approach' to student project teams than found at other schools - specifically, using MBA students as project advisors as well as stating the assessment of the competencies of integrity and professionalism for project team members as an explicit goal in the course's evaluation system. (The MCFE grading system will be discussed more specifically in Chapter 4.)

\section{A Focus on Entrepreneurship}

The undergraduate MCFE program and the consulting team programs in our graduate school are aligned with the college's mission to provide business education with an emphasis on entrepreneurship. That mission can be traced back to founder Roger Babson, a successful Boston area entrepreneur, and has contributed to Babson College's year-after-year ranking as one of the best US colleges for entrepreneurial studies. The college's incoming undergraduate first-year class gets its first exposure to that mission in Babson's mandatory Foundations of Management and Entrepreneurship (FME) course. During that year-long course, two faculty members - with business experience and representing the disciplines of entrepreneurship and organizational behaviorteam-teach the ins and outs of different disciplines including entrepreneurship, innovation, teamwork and collaboration, marketing, accounting, organizational behavior and operations while emphasizing the integrated role these functions have in a business. Students are organized into teams that create and manage real businesses; each team can receive up to $\$ 5000$ in a start-up loan for that purpose. Those businesses are terminated at the end of the school year (with loans hopefully repaid), and all profits go to charities that the students select. Since 2000, FME businesses have contributed more than $\$ 500,000$ to local charities. FME sets the tone for undergraduate studies and experiential learning at Babson.

In our consulting teams, students apply Babson's Entrepreneurial Thought and Action $^{\circledR}$ (ET\&A $\left.{ }^{\mathrm{TM}}\right)$ model, which encourages them to think differently about the challenges they face in their consulting projects and to balance action, experimentation and creativity with a deep understanding of business 
fundamentals and rigorous analysis as the ideal approach to creating economic and social value. According to Professor Heidi Neck (2019) at Babson,

ET\&A $\mathrm{A}^{\mathrm{TM}}$ requires a specific mindset. Not only must we alter our ways of thinking in order to see the endless possibilities in the world, but we must also go a step further and intentionally create mindshifts. Where a mindset is something you have, a mindshift is something you create through action. These mindshifts are created through the practice of ET\& $\mathrm{A}^{\mathrm{TM}}$.

ET\&A ${ }^{\mathrm{TM}}$ has several guiding principles that students are encouraged to use in working with their teams and clients, as explained on Babson College's website (2019):

- Take the First Step: From one action, you'll get new data and information that you can use to guide further action and to reassess and adjust your goal as necessary. Then you'll take the next step. And then the next, and the next, until you've overcome some obstacles, adapted to others and accomplished your goal - though likely not the one with which you started.

- Make a Difference: Above all, what you do matters and can make a difference.

- Get Started: The good news is we don't believe entrepreneurial leaders are individuals who are born with this set of characteristics. You can learn to act and think entrepreneurially to create the future you want.

\section{The MCFE Program Design and Benefits}

For those who qualify, the undergraduate MCFE elective provides a rigorous, one-semester capstone experience. To be accepted to the MCFE program, students must have a defined number of college credits (consequently, they are typically third- or fourth-year students), have a specified grade point average and have the recommendation of a faculty member regarding the ability of the student to do quality work and to be able to collaborate with others.

In our current undergraduate MCFE program, student teams meet once a week by themselves for a minimum of two hours and for approximately two hours with their project advisors where they also receive ongoing coaching and feedback around team and individual performance. (As opposed to our graduate programs, project advisors in our undergraduate program have only one team to manage.) Additionally, all project advisors meet once a week in class together with the program's faculty director to discuss leadership, team and client issues they have encountered. In this way, project advisors receive coaching from each other as well as from the faculty director. In addition to using graduate students, project advisors can also be faculty, alumni, executives in residence or other experienced individuals who oversee the functioning 
of the teams. (The graduate program mainly uses faculty as project advisors for student consulting teams, occasionally utilizing executives in residence for the role.) Regardless of the approach used to manage student consulting teams, extensive research by the Gallup Organization (Levy \& Sidhu, 2013) makes it clear that a caring and supportive faculty (in our case, project advisors) plays a key role in student learning.

The experiential learning approach in the MCFE program involves various participants — client companies, students, project advisors (including faculty), program deans and administrators. Each derives clear benefits from this program:

- Client companies get the benefit (generally without cost) of problem/ opportunity analysis and recommendations for tackling such problems and opportunities. For example, the appliance division of a large global manufacturing and service company asked a Babson student team to analyze its situation and help create a growth plan. To that entity's surprise, the students recommended that the appliance division be spun out as a non-strategic asset. That recommendation was later adopted and implemented. Another student team helped a small entrepreneurial snack food firm solve a challenging marketing problem. The team's outcome contributed to the successful sale of the firm to a major food company.

- Students learn what professionalism in the workplace should look like while building and developing their project management and consulting skills. They also learn to analyze problems and deliver fact-based recommendations to senior business leaders. They hone teamwork and presentation skills that will help them in their careers. And they observe invaluable connections between what they are learning in the classroom and what they will encounter in the workplace upon graduation.

- Project advisors (faculty, executives in residence with industry experience, alumni and MBA students here at Babson) provide leadership to our undergraduate student consulting teams to organize their efforts and help teams stay on track. These advisors utilize and sharpen their project management, coaching, assessment and team leadership capabilities to help teams operate at a higher level than if they were left to their own devices. In addition, when faculty serve as project advisors, they often find new ways to relate to students and to guide the students' understanding of academic concepts. Faculty have traditionally relied on classroom participation and testing to assess the progress of individual students and to identify areas where faculty intervention is needed. Student behavior in real-world consulting settings gives faculty members an additional picture of student learning. 
- Deans, administrators and college presidents enhance the educational value of their institutions when they offer experiential learning. In the intensely competitive world of higher education, wherein each school is trying to attract the best and the brightest, being able to offer students a career-building field experience is a powerful differentiator that helps to makes a school 'special.' But more importantly, it also contributes significantly to a student's learning and career development.

Experiential learning can be a winner for all participants. From Babson's founding in 1919 to one hundred years later, as we look at ways of strengthening our curricula across all of our programs, Babson continues to make experiential learning a large part of our learning model.

\section{One Student's Experience}

'MCFE was the most important part of my undergraduate education - a transformative experience that made me a much better strategic thinker.' That is how David Sachs (a 1988 Babson alumnus) describes his MCFE project.

Sachs's senior year at Babson coincided with a project from a large worldwide manufacturing and service company, which at that time was a conglomerate with a presence in the consumer large appliance industry with a number of major brands. 'They were considering expanding their appliance platform and asked us to evaluate the industry and the merits of acquiring a publicly traded appliance rival,' Sachs recalls. 'Frankly, I think the chairman of the appliance division saw this as a make-work project for us - an opportunity for some Babson students to get some experience - not something of immediate value to his business. But that's not how it turned out.'

Sachs and his small team spent the next six weeks doing an industry analysis and building a fact file. Their analysis extended beyond the 'target' company to the company's own appliance division. Then, mid-semester, the target Sachs and his team had been tasked to assess received multiple hostile takeover bids from strategic suitors. Within the client company, only the Babson team was current on the fundamentals, valuation and theoretical synergistic attributes of combining with the target company. To educate the client's board of directors on these matters and the evolving competitive landscape, the appliance division's chairman asked the students to present their findings and recommendations to the client's board-heady stuff for a team of 21-year-olds.

What the board members heard from Sachs's team was not what they had expected. Sachs (2020) explains,

We told them that they shouldn't acquire the target company. In fact, given the high level of competitive interest and valuation the target had attracted, we recommended 
that the client sell its own appliance business. The client's core manufacturing and service business was solid, producing high returns year after year. Its appliance business, on the other hand, was an under-earning asset with a low return on capital, with an undifferentiated product line in a cyclical, commoditized market. It produced anemic returns in good years and broke even or lost money in others. For our client, consumer appliances were essentially a distraction. And so we recommended that they exit that business, and not pursue growth through acquisition.

Neither Sachs nor his team knew anything about the appliance industry when they began their project, but by the end they had learned enough to make a high-impact presentation to the client's board. They also honed their skills in analysis, valuation and corporate strategy to a much higher level than what could be taught in the classroom. After graduation, Sachs used those skills to build a highly successful Wall Street career and, later, to create a private investment management firm in partnership with his wife. A MCFE teammate was offered a job with the client upon graduation, which he accepted and continued in for over ten years. While it took a few years before the company heeded the team's recommendation, the company did end up selling its appliance business.

In the years that followed, Sachs became an unofficial ambassador for the undergraduate MCFE program, helping it connect with high-profile businesses in a variety of locations and industries including a major league baseball team, a large craft beer company, a television network, a major venture capital firm and an international manufacturer of consumer sound systems and speakers. The projects that emanated from those relationships and others enabled subsequent generations of Babson students to have the same opportunity to benefit from experiential learning. For over 30 years, many of the students in our MCFE program have felt that the learning they gained was one of the most powerful learning experiences they had at the college. As a result of those and similar experiences in MCFE, and with the strong support of Babson's undergraduate dean and provost, the number of consulting projects per semester expanded by 50 percent beginning in 2017 .

\section{WHAT'S IN IT FOR THE CLIENT COMPANY? EXAMPLES AND ADVICE}

The long history of the MCFE program is filled with examples of young minds creating value for companies. Recognizing that, many companies ask for more - in fact, some clients have hosted ten or more MCFE project teams. As Arline MacCormack, associate director of experiential programs at Babson and one of the authors of this book, stated, 'Clients wouldn't be coming back for more if they weren't seeing tangible benefits.' Among other benefits, MCFE students can help experienced executives connect with students from 
a different generation. In 2020, our students are now referred to as 'Gen Z.' These students often come with no preconceived ideas, no turf issues to defend and no emotional attachments to existing programs or strategies that often hamstring company executives. Several projects for large consumer companies have already centered on the consumer preferences of Gen Z students.

Alps \& Meters founder and CEO Louis Joseph (a 2005 Babson MBA graduate) has hosted 11 undergraduate project teams between 2010 and 2020, both at a large worldwide athletic shoe and sportswear company for which he formerly worked as head of product innovation, and now at his own high-end outdoor apparel start-up, Alps \& Meters. 'And not one of those teams failed to deliver,' Joseph stated. 'These students bring intelligence, rigor and professionalism to important business problems, and they really do their homework.' They have been a valuable resource for his small and growing company. 'It's been a no-brainer,' he continued. 'Student consultants cost me nothing and demand very little of my time once we've on-boarded them. Yet they package their analysis and conclusions very well - to the point that I can confidently share their findings with my team, board and investors.'

Joseph was particularly pleased with a MCFE team's work on a strategic decision facing his young company in early 2017. According to Joseph (2019),

We had been struggling with the idea of expanding into the women's apparel market. There'd already been strenuous debate about this at the board level, but we didn't have enough information to make a good decision. We had to better understand the risks and the competition, assess the level of resources needed to succeed, develop a sales forecast and position strategy, and so forth. We gave that job to a MCFE team, knowing that the team would have more time to work on the problem. After a semester of work they handed us conclusions and recommendations that we started implementing.

Stacy Madison is another regular sponsor of MCFE projects. Madison founded Stacy’s ${ }^{\circledR}$ Pita Chip Company in 1997 as a tiny start-up and grew it into a company with $\$ 65$ million in annual sales. She sold it to the Frito-Lay division of PepsiCo in 2006. After several years with a private equity firm in the Boston area, she launched another entrepreneurial enterprise-Stacy's Juice Bar-in 2013 in Needham, Massachusetts. That venture makes and serves healthy juices and lunch options; in mid-2017 it launched a local catering division, and in 2019 a Babson student consulting team worked with the company on introducing a new food product: BeBOLD Energy Bars.

Madison's relationship with MCFE began around 1999. Between then and late 2019, she tapped into the talents of over 75 students on more than a dozen projects. 'They are a joy to have,' she said. 'They've worked on everything from soup to nuts: finance, marketing, product promotions and more. Some developed processes that we've implemented over and over again.' She espe- 
cially values the insights that student consulting teams bring to her business. 'They have tech know-how and insights into the customer population that an older business owner might not have. Business today is very different than it was 30 years ago, and these kids are on top of it.'

To make the most of MCFE teams, Madison (2019) offers this advice to business sponsors/clients:

- Think ahead. 'The most difficult part of being a MCFE client is coming up with a good project in advance of the students' participation. Ask yourself, "What will I want a team to do six months from now?" That hasn't been easy for me because I'm so immersed in the immediate needs of the business.'

- Match projects to the real needs of the company. 'Our most successful projects were properly matched.'

- Focus student projects. 'I've learned from experience to stay away from broad, general projects. Projects with limited scope that focus on key problems or opportunities have been the most productive for us.'

We are fortunate to have learned so much from our clients as described above. In the next chapter, we will discuss some of the key concepts and best practices that serve as a foundation for successfully managing student consulting teams.

\section{REFERENCES}

Babson College Entrepreneurial Thought \& Action ${ }^{\circledR}$. Retrieved November 17, 2019 from https://www.babson.edu/about/at-a-glance/entrepreneurial-thought--action/.

Colby, A., Ehrlich, T., Sullivan, W. M. \& Dolle, J. R. (2011). Rethinking Undergraduate Business Education: Liberal Learning for the Profession. San Francisco, CA: Jossey-Bass.

Cox, E. (2019). Experiential learning and learning styles. International Studies Association and Oxford University Press (original work published 2010). doi:10 .1093/acrefore/9780190846626.013.175.

Joseph, L. (2019). Email communication with A. MacCormack, October 23.

Levy, J. \& Sidhu, P. (2013). In the U.S., 21st century skills linked to work success. Gallup. Retrieved from https://news.gallup.com/poll/162818/21st-century-skills -linked-work-success.aspx.

Madison, S. (2019). Email communication with A. MacCormack, October 23.

Neck, H. (2019). A note on the components of Entrepreneurial Thought \& Action $\mathbb{R}$ [PDF file]. Retrieved from https://www.babson.edu/media/babson/site-assets/ content-assets/about/academics/centres-and-institutes/the-lewis-institute/fund-for -global-entrepreneurship/Entrepreneurial-Thought-and-Action-(ETA).pdf.

Sachs, D. (2020). Email communication with J. Weintraub, January 19.

Scisco, P., Biech, E. \& Hallenbeck, G. (2017). Compass: Your Guide for Leadership Development and Coaching. Greensboro, NC: CCL Press. 